\title{
AKUPRESUR EFEKTIF MENGATASI DISMENOREA
}

\author{
Abel Zulia, Heni Setyowati Esti Rahayu*, Rohmayanti \\ Program Studi Ilmu Keperawatan, Universitas Muhammadiyah Magelang \\ Jl. Mayjend Bambang Soegeng, Mertoyudan, Magelang, Jawa Tengah, Indonesia \\ *)E-mail: henisetyawati@ummgl.ac.id
}

Dikirim: November 2016, diterbitkan: April 2017

\begin{abstract}
ABSTRAK
Tujuan penelitian: untuk membandingkan efektivitas antara aromaterapi lavender dan akupresur dalam mengatasi dismenorea. Metode: Rancangan penelitian yang digunakan adalah quasy experiment dengan two group pretest dan posttest design. Penelitian dilakukan di Fakultas Ilmu Kesehatan Universitas Muhammadiyah Magelang tanggal 14 Maret sampai 9 Mei 2015. Sampel sebanyak 44 responden dibagi menjadi dua kelompok, yaitu 22 orang sebagai kelompok aromaterapi lavender dan 22 orang sebagai kelompok terapi akupresur. Aromaterapi diberikan secara inhalasi selama 10 menit, dilakukan dua kali sehari selama 3 hari. Akupresur dilakukan pada LI 4 dan ST 36 selama 20 menit sebanyak dua kali sehari selama 3 hari. Instrumen untuk mengukur nyeri menggunakan numeric rating scale. Uji statistik yang digunakan adalah uji Mann Whitney. Hasil: Terdapat perbedaan antara aromaterapi lavender dan terapi akupresur dalam mengat asi dismenore dengan perbedaan penurunan intensitas nyeri terapi akupresur 1,95 lebih besar daripada aromaterapi lavender 1,46 dengan nilai $p=0,002$. Diskusi: Terapi akupresur dengan pemijatan atau penekanan pada titik LI 4 dan ST 36 akan meningkatkan kadar endorfin sehingga lebih cepat menurunkan rasa nyeri, sedangkan aroma yang dihirup melalui proses pernapasan baru merangsang kinerja otak dan dipengaruhi oleh dalamnya pernapasan. Kesimpulan: Terapi akupresur lebih efektif dalam mengatasi dismenorea daripada aromaterapi lavender.
\end{abstract}

Kata Kunci: dismenorea, aromaterapi lavender, akupresur

\section{EFFECTIVENESS OF ACUPRESSURE IN TREATING DYSMENORRHOEA} ABSTRACT

Objective: To compare the effectiveness of lavender aromatherapy and acupressure in treating dysmenorrhea. Methods: This study is a quasi-experiment with two group pretest and posttest design. The study was conducted at the Faculty of Health Sciences, Muhammadiyah University of Magelang on 14 March 2015 to 9 May 2015. Samples consisting of 44 respondents were divided into two groups, namely 22 in lavender aromatherapy group and 22 in acupressure therapy group. Aromatherapy was given through inhalation for 10 minutes, done twice a day for 3 days. Acupressure was performed on LI 4 and ST 36 for 20 minutes, twice a day for 3 days. Numerical rating scale was used for measuring pain. The statistical test used Mann-Whitney test. Results: There was a difference between lavender aromatherapy and acupressure therapy in treating dysmenorrhea with a decrease in the intensity of pain of acupressure therapy by 1.95, which was greater than lavender aroma by 1.46 with $p=0.002$. Discussion: Acupressure therapy with massage or pressure on the points of LI 4 and ST 36 would increase endorphin levels so that it would quickly relieve pain, while the inhaled scent through the breathing process only stimulated brain's performance and was affected by the depth of breathing. Conclusion: Acupressure therapy is more effective in treating dysmenorrhea than lavender aromatherapy.

Keywords: dysmenorrhea, lavender aromatherapy, acupressure 


\section{LATAR BELAKANG}

Dismenorea adalah nama medis untuk menstruasi yang disertai dengan keram dan rasa sakit yang berlebihan (Morgan \& Hamilton, 2009). Dismenorea adalah menstruasi yang disertai nyeri dan merupakan masalah ginekologi yang sering dikeluhkan oleh 40-80\% wanita muda (Hegner, 2003; Benson \& Pernoll, 1993/2009). Dismenorea terjadi karena endometrium dalam fase sekresi memproduksi prostaglandin berlebihan, prostaglandin (PGF-2 $\alpha$ ) yang menyebabkan hipertonus dan vasokontriksi pada miometrium sehingga mengakibatkan iskemia, disintegrasi endometrium, perdarahan, dan nyeri (Morgan \& Hamilton, 2009).

Dismenorea biasanya terjadi 24-48 jam sebelum menstruasi dan mereda setelah timbul menstruasi. Nyeri bersifat konstan, biasanya pada pelvis atau punggung bawah (sakrum) dan dapat menyebar ke selangkangan atau tungkai bawah (Benson \& Pernoll, 1993/2009). Dismenorea juga sering disertai dengan mual, muntah, sakit kepala, pingsan dan nyeri tungkai (Morgan \& Hamilton, 2009).

Terapi yang digunakan untuk mengatasi dismenorea dapat dilakukan secara farmaka dan nonfarmaka. Terapi farmaka memiliki efek samping yang merugikan sehingga diupayakan pemberian terapi secara nonfarmaka di antaranya aromaterapi dan akupresur. Aromaterapi merupakan penggunaan minyak esensial konsentrasi tinggi yang diekstrak dari tumbuh-tumbuhan dan diberikan melalui pijatan, inhalasi, dicampur ke dalam air mandi, dan untuk kompres.

Aromaterapi yang dapat digunakan untuk mengatasi dismenorea ialah aromaterapi lavender karena aromaterapi ini salah satu khasiatnya merilekskan (Sharma, 2009). Aromaterapi lavender berasal dari bagian bunga dan kelopak bunga dan merupakan salah satu minyak terapi yang sangat populer. Aromaterapi lavender bisa digunakan untuk masalah gangguan menstruasi, khususnya dismenorea karena mempunyai efek relaksasi maupun perangsang, menenangkan kecemasan dan depresi (Kozier et al., 2012). Kandungan utama dari bunga lavender ialah linalil asetat dan linalool $\left(\mathrm{C}_{10} \mathrm{H}_{18} \mathrm{O}\right)$ yang berperan pada efek relaksasi bagi saraf dan otot-otot yang tegang. Berdasarkan hasil penelitian Dehkordi, Baharanchi, \& Bekhradi (2014) tentang pengaruh inhalasi aromaterapi lavender pada gejala dismenorea primer dan jumlah perdarahan saat menstruasi di Iran, didapatkan hasil bahwa dismenorea berkurang setelah diberikan inhalasi aromaterapi lavender dengan nilai $p<0,001$ yang dianggap signifikan.

Terapi nonfarmaka lain yang dapat digunakan untuk mengatasi dismenore adalah akupresur. Akupresur adalah pengobatan dari Tiongkok yang sudah dikenal sejak ribuan tahun lalu dan dengan memberikan tekanan atau pemijatan dan menstimulasi titik-titik tertentu dalam tubuh. Salah satu efek penekanan titik akupresur ialah dapat meningkatkan kadar endorfin yang berguna sebagai pereda nyeri yang diproduksi tubuh dalam darah dan opioid peptida endogeneus di dalam susunan saraf pusat (Hartono, 2012). Jaringan saraf akan memberi stimulus pada sistem endokrin untuk melepaskan endorfin sesuai kebutuhan tubuh dan diharapkan dapat menurunkan rasa nyeri saat menstruasi (Widyaningrum, 2013). Titik yang dapat digunakan untuk mengatasi dismenore antara lain titik LI 4, titik SP 6, titik SP 8, titik ST 36, titik CV 3 dan CV 4 (Gharloghi et al., 2012).

Penelitian ini bertujuan untuk mengetahui perbandingan efektivitas antara aromaterapi lavender dan terapi akupresur dalam 
mengatasi dismenorea pada mahasiswi Fakultas IImu Kesehatan Universitas Muhammadiyah Magelang.

\section{METODE}

Penelitian ini merupakan penelitian kuasi eksperimen dengan two group pretest and posttest design. Uji etik telah dilakukan oleh Komisi Etik Penelitian Fakultas IImu Kesehatan Universitas Muhammadiyah Magelang. Penelitian ini dilakukan di Fakultas IImu Kesehatan Universitas Muhammadiyah Magelang dari tanggal 14 Maret sampai 9 Mei 2015. Besar sampel diambil dengan menggunakan rumus 2 mean (rerata) kelompok tidak berpasangan (unpaired). Sampel sebanyak 44 responden dibagi menjadi dua kelompok, yaitu sebanyak 22 orang sebagai kelompok aromaterapi lavender dan 22 orang sebagai kelompok terapi akupresur yang diundi menggunakan koin.

Untuk menentukan jumlah sampel masing-masing program studi, dilakukan proportional random sampling dengan kriteria inklusi remaja putri yang bersedia menjadi responden dan remaja putri yang mengalami dismenorea sehingga didapatkan Prodi S-1 IImu Keperawatan tingkat I sebanyak 6 mahasiswi, tingkat II sebanyak 8 mahasiswi, dan tingkat III sebanyak 6 mahasiswi. Prodi D-3 Keperawatan tingkat I sebanyak 7 mahasiswi dan tingkat II sebanyak 9 mahasiswi. Prodi D-3 Farmasi tingkat I sebanyak 4 mahasiswi dan tingkat II sebanyak 4 mahasiswi. Sebelum penelitian, responden diwajibkan menyampaikan tanggal menstruasi, kemudian ditindaklanjuti dengan SMS (short message service) pada saat menstruasi hari pertama.
Prosedur tindakan pada penelitian ialah pemberian aromaterapi lavender dengan menuangkan tiga tetes minyak esensial pada tisu, kemudian menghirupnya selama 10 menit, dilakukan 2 kali dalam sehari, yaitu pagi pukul 10.00 dan sore pukul 16.00 selama 3 hari. Prosedur tindakan akupresur dilakukan oleh peneliti dengan memberikan penekanan pada dua titik, yaitu titik large intestine 4 (LI 4) atau hoku/he-qu dan titik stomach 36 (ST 36) atau zusanli. Penekanan kedua titik tersebut dilakukan 40 kali di setiap titiknya, dilakukan 2 kali dalam sehari selama 3 hari. Pemberian aromaterapi dan akupresur dilakukan oleh peneliti pada hari pertama, hari kedua, dan hari ketiga menstruasi. Waktunya ditentukan oleh peneliti dengan mempertimbangkan waktu responden.

Pengukuran skala nyeri menggunakan numeric ratting scale (NRS) merupakan instrumen yang sudah valid dan reliabel dengan $r=0,96$ (Ferraz et al., 1990; Williamson \& Hoggart, 2005). Terdapat angka 0 sampai dengan 10 . Angka 0 dideskripsikan tidak ada nyeri, 1-3 nyeri ringan, 4-6 nyeri sedang, 7-9 nyeri berat, dan 10 nyeri hebat. NRS diberikan kepada responden sebelum diberikan tindakan dan dijadikan sebagai data sebelum, kemudian NRS diberikan lagi setelah tindakan kedua pada hari tersebut sebagai data setelah tindakan hari pertama. Kemudian, sebelum tindakan hari kedua NRS diberikan lagi ke responden sebagai data sebelum tindakan hari kedua dan setelah tindakan yang kedua NRS diberikan lagi sebagai data setelah tindakan hari kedua. Demikian halnya pada hari ketiga. Analisis dilakukan dengan uji Mann Whitney. 


\section{HASIL}

\section{Karakteristik Responden}

Tabel 1. Gambaran karakteristik responden tindakan aromaterapi lavender dan terapi akupresur pada mahasiswi Fakultas IImu Kesehatan Universitas Muhamadiyah Magelang yang mengalami dismenorea tahun 2015

\begin{tabular}{|c|c|c|c|c|c|c|c|}
\hline \multirow{2}{*}{ Variabel } & \multicolumn{3}{|c|}{ Aromaterapi Lavender } & \multicolumn{3}{|c|}{ Akupresur } & \multirow{2}{*}{ Homogenitas } \\
\hline & $n$ & Mean & $\mathrm{SD}$ & $n$ & Mean & SD & \\
\hline Usia & 22 & 19,77 & 0,972 & 22 & 19,72 & 0,984 & 0,607 \\
\hline Lama Haid & 22 & 6,36 & 0,902 & 22 & 6,04 & 0,898 & 0,96 \\
\hline
\end{tabular}

Berdasarkan Tabel 1, dapat disimpulkan bahwa kedua kelompok responden mempunyai varian sama atau homogen. Tidak ada perbedaan usia dan lama haid antara kelompok tindakan aromaterapi lavender dan terapi akupresur.

\section{Intensitas Nyeri}

Perbedaan rata-rata intensitas nyeri dismenorea pada kelompok aromaterapi sebelum dan setelah pemberian aromaterapi pada hari pertama, kedua, dan ketiga dapat dilihat pada Tabel 2 berikut ini.

Tabel 2. Perbedaan rata-rata intensitas nyeri dismenorea kelompok aromaterapi sebelum dan setelah dilakukan aromaterapi hari 1, 2, dan 3

\begin{tabular}{|c|c|c|c|c|c|}
\hline \multicolumn{2}{|c|}{ Variabel } & Mean & Mean Different & SD & $\mathrm{p}$ value \\
\hline \multirow{2}{*}{$\begin{array}{c}\text { Dismenorea } \\
\text { Hari } 1\end{array}$} & Sebelum & 5,36 & \multirow{2}{*}{1,18} & 0,658 & \multirow{2}{*}{$<0,001$} \\
\hline & Setelah & 4,18 & & 0,664 & \\
\hline \multirow{2}{*}{$\begin{array}{c}\text { Dismenorea } \\
\text { Hari } 2\end{array}$} & Sebelum & 3,95 & \multirow{2}{*}{1,18} & 0,899 & \multirow{2}{*}{$<0,001$} \\
\hline & Setelah & 2,77 & & 0,813 & \\
\hline \multirow{2}{*}{$\begin{array}{c}\text { Dismenorea } \\
\text { Hari } 3\end{array}$} & Sebelum & 2,59 & \multirow{2}{*}{1,46} & 0,854 & \multirow{2}{*}{$<0,001$} \\
\hline & Setelah & 1,13 & & 0,639 & \\
\hline
\end{tabular}

*Uji Wilcoxon

Tabel 2 menunjukkan bahwa perbedaan rata-rata intensitas nyeri dismenorea sebelum dan setelah dilakukan aromaterapi pada hari pertama dan hari kedua ialah 1,18 dengan $p<0,001$. Hal ini berarti ada perbedaan yang signifikan antara sebelum dan setelah diberikan aromaterapi.

Perbedaan rata-rata intensitas nyeri dismenorea sebelum dan setelah dilakukan aromaterapi pada hari ketiga ialah 1,46 dengan $p<0,001$. Hal ini berarti ada perbedaan yang signifikan antara sebelum dan setelah diberikan aromaterapi.

Perbedaan rata-rata intensitas nyeri dismenorea pada kelompok terapi akupresur sebelum dan setelah terapi akupresur pada hari pertama, kedua, dan ketiga dapat dilihat pada Tabel 3 berikut ini.

Tabel 3. Perbedaan intensitas nyeri dismenorea kelompok akupresur sebelum dan setelah dilakukan akupresur hari 1, 2, dan 3

\begin{tabular}{|c|c|c|c|c|c|}
\hline \multicolumn{2}{|c|}{ Variabel } & Mean & Mean Different & SD & $\mathrm{p}$ value \\
\hline \multirow{2}{*}{$\begin{array}{c}\text { Dismenorea } \\
\text { Hari } 1\end{array}$} & Sebelum & 5,40 & \multirow{2}{*}{1,45} & 0,734 & \multirow{2}{*}{0,001} \\
\hline & Setelah & 3,95 & & 0,785 & \\
\hline \multirow{2}{*}{$\begin{array}{c}\text { Dismenorea } \\
\text { Hari } 2\end{array}$} & Sebelum & 3,95 & \multirow{2}{*}{1,86} & 0,785 & \multirow{2}{*}{0,001} \\
\hline & Setelah & 2,09 & & 0,684 & \\
\hline \multirow{2}{*}{$\begin{array}{c}\text { Dismenorea } \\
\text { Hari } 3\end{array}$} & Sebelum & 2,40 & \multirow{2}{*}{1,95} & 0,959 & \multirow{2}{*}{0,001} \\
\hline & Setelah & 0,45 & & 0,739 & \\
\hline
\end{tabular}

*Uji Wilcoxon 
Tabel 3 menunjukkan bahwa perbedaan rata-rata intensitas nyeri dismenore sebelum dan setelah dilakukan akupresur pada hari kesatu adalah 1,45 dengan $p<0,001$. Hal ini berarti bahwa ada perbedaan yang signifikan antara sebelum dan setelah diberikan terapi akupresur.

Intensitas nyeri dismenorea pada hari kedua nyeri dismenorea sebelum dan setelah dilakukan akupresur adalah 1,86 dengan $p<0,001$. Hal ini berarti ada perbedaan yang signifikan antara sebelum dan setelah diberikan terapi akupresur. Sementara itu, perbedaan rata-rata intensitas nyeri dismenorea sebelum dan setelah dilakukan terapi akupresur hari ketiga ialah 1,95 dengan $p<0,001$. Hal ini berarti ada perbedaan yang signifikan antara sebelum dan setelah diberikan terapi akupresur.

Perbedaan intensitas nyeri dismenorea setelah diberikan tindakan aromaterapi lavender dan terapi akupresur pada hari pertama, kedua, dan ketiga dapat dilihat pada Tabel 4 berikut ini.

Tabel 4. Perbedaan penurunan intensitas nyeri dismenorea setelah diberikan tindakan aromaterapi lavender dan terapi akupresur

\begin{tabular}{|c|c|c|c|}
\hline Tindakan & Mean & $\begin{array}{c}\text { Mean } \\
\text { Different }\end{array}$ & p value \\
\hline Akupresur 1 & 1,45 & \multirow{2}{*}{0,27} & \multirow{2}{*}{0,356} \\
\hline Aromaterapi 1 & 1,18 & & \\
\hline Akupresur 2 & 1,86 & \multirow{2}{*}{0,68} & \multirow{2}{*}{0,004} \\
\hline Aromaterapi 2 & 1,18 & & \\
\hline Akupresur 3 & 1,95 & \multirow{2}{*}{0,49} & \multirow{2}{*}{0,002} \\
\hline Aromaterapi 3 & 1,46 & & \\
\hline
\end{tabular}

*Uji Mann Whitney

Berdasarkan Tabel 4, pada hari pertama setelah diberikan aromaterapi lavender dan terapi akupresur tidak ada perbedaan penurunan intensitas nyeri yang signifikan. Pada hari kedua setelah diberikan aromaterapi lavender dan terapi akupresur didapatkan ada perbedaan penurunan intensitas nyeri yang signifikan. Pada hari ketiga setelah diberikan aromaterapi lavender dan terapi akupresur disimpulkan bahwa ada perbedaan penurunan nyeri yang signifikan antara aromaterapi lavender dan terapi akupresur dalam mengatasi dismenorea pada mahasiswi Fakultas IImu Kesehatan Universitas Muhammadiyah Magelang. Dengan demikian, dari kedua terapi tersebut yang lebih efektif dalam mengatasi dismenorea ialah terapi akupresur dengan rata-rata 1,95, lebih besar daripada rata-rata aromaterapi lavender sebesar 1,46.

\section{DISKUSI}

Penurunan intensitas nyeri menstruasi yang dialami oleh responden setelah diberikan terapi akupresur terjadi karena terapi ini memiliki efek analgesik dengan cara merangsang atau menstimulasi serabut saraf berdiameter besar A-beta sehingga menurunkan transmisi impuls nyeri melalui serabut kecil A-delta dan serabut saraf $\mathrm{C}$. Rangsangan pada sel $\mathrm{T}$ juga berkurang dan kemudian korteks cerebri menginterpretasikan kualitas informasi sensorik pada tingkat kesadaran. Akhirnya, nyeri menstruasi tidak diteruskan ke pusat nyeri sehingga nyeri berkurang (Tamsuri, 2007). Selain itu, menurut teori endorfin, terapi akupresur ini dapat meningkatkan kadar endorfin dalam tubuh sehingga nyeri yang dirasakan berkurang (Hartono, 2012).

Efek penekanan titik akupresur terkait dengan dampaknya terhadap produksi endorfin dalam tubuh. Endorfin adalah pembunuh rasa nyeri yang dihasilkan sendiri oleh tubuh. Endorfin merupakan molekulmolekul peptid atau protein yang dibuat dari zat yang disebut beta lipoptropin yang ditemukan pada kelenjar pituitari. Endorfin mengontrol aktivitas kelenjar-kelenjar endokrin tempat molekul tersebut tersimpan.

Pelepasan endorfin dikontrol oleh sistem saraf. Saraf sensitif terhadap nyeri 
dan rangsangan dari luar dan begitu dipicu dengan menggunakan teknik akupresur akan menginstruksikan sistem endokrin untuk melepaskan sejumlah endorfin sesuai kebutuhan tubuh (Hartono, 2012). Namun, dalam penelitian ini, peneliti tidak mengukur kadar hormonal, yaitu kadar endorfin yang dapat mengurangi rasa nyeri dismenorea.

Faktor-faktor yang bisa menimbulkan nyeri dismenorea salah satunya faktor stres. Tubuh akan bereaksi saat mengalami stres. Faktor stres ini dapat menurunkan ketahanan terhadap rasa nyeri. Tanda pertama yang menunjukkan keadaan stres idalah adanya reaksi yang muncul, yaitu menegangnya otot tubuh individu dipenuhi oleh hormon stres yang menyebabkan tekanan darah, detak jantung, suhu tubuh, dan pernapasan meningkat.

Di sisi lain, saat stres, tubuh akan memproduksi hormon adrenalin, estrogen, progesteron, serta prostaglandin yang berlebihan. Estrogen dapat menyebabkan peningkatan kontraksi uterus secara berlebihan, sedangkan progesteron bersifat menghambat kontraksi. Peningkatan kontraksi secara berlebihan ini menyebabkan rasa nyeri. Selain itu, hormon adrenalin juga meningkat sehingga menyebabkan otot tubuh tegang, termasuk otot rahim dan dapat menjadikan nyeri ketika haid (Hendrawan, 2008).

Bobak, Lowdermilk, \& Jensen (1995/2005) menyatakan bahwa nyeri menstruasi diakibatkan adanya pelepasan PGF2a yang berlebihan sehingga meningkatkan amplitudo dan frekuensi kontraksi uterus yang menyebabkan vasospasme arteriol uterus sehingga terjadi iskemia dan keram abdomen bawah yang bersifat siklik. Penekanan pada titik hoku/he-qu (L14) dapat memberikan asupan energi pada organ reproduksi dan meredakan nyeri secara umum. Sementara itu, penekanan pada titik zusanli (ST 36) bermanfaat untuk meningkatkan stamina dalam tubuh sehingga mengurangi dismenorea (Widyaningrum, 2013).

Penelitian yang mendukung penelitian efek terapi akupresur terhadap dismenorea ialah penelitian yang dilakukan oleh Julianti, Hasanah, \& Erwin (2011) yang dilakukan terhadap 80 responden. Penelitian ini dilakukan terapi akupresur pada titik taichong (LR3) dan titik neiguan (PC6). Penekanan dilakukan pada saat menstruasi selama 3 hari. Hasil akhir menunjukkan bahwa responden merasakan nyeri menstruasi berkurang atau dengan kata lain secara signifikan akupresur dapat menurunkan rata-rata intensitas nyeri sebesar 1,76 poin $(\alpha<0,05)$.

Selanjutnya, penelitian yang dilakukan Hasanah (2010). Penelitian ini dilakukan terapi akupresur pada titik taichong (LR3). Penekanan dilakukan pada fase lutheal. Hasil akhir menunjukkan bahwa responden merasakan nyeri menstruasi berkurang atau dengan kata lain, secara signifikan akupresur dapat menurunkan rata-rata kualitas nyeri sebesar 1,852 poin $(\alpha<0,05)$.

Dismenorea merupakan suatu keadaan yang normal, tetapi dapat berlebihan apabila dipengaruhi oleh faktor fisik dan psikis seperti stres serta pengaruh dari hormon prostaglandin dan progesteron. Selama dismenorea, terjadi kontraksi otot rahim akibat peningkatan prostaglandin sehingga menyebabkan terjadinya iskemia dan keram pada abdomen bagian bawah yang merangsang nyeri menstruasi (Morgan \& Hamilton, 2009).

Aromaterapi merupakan penggunaan minyak esensial dari tanaman untuk meningkatkan kesehatan, vitalitas tubuh, pikiran, serta jiwa dengan cara inhalasi, mandi rendam, kompres, pemakaian topikal, dan pijat. Pemakaian minyak esensial secara komersial untuk terapi stres dan pencegahan 
penyakit sudah dilakukan sejak ratusan tahun (Sharma, 2009).

Linalool merupakan kandungan aktif utama yang berperan pada efek anticemas (relaksasi) pada lavender. Berdasarkan hasil beberapa jurnal penelitian, minyak esensial dari bunga lavender dapat memberikan manfaat relaksasi (carminative), mengurangi nyeri dismenorea, sedatif, mengurangi tingkat kecemasan, dan mampu memperbaiki mood seseorang. Aromaterapi lavender juga terbukti dapat merangsang kerja endorfin pada kelenjar pituitari dan menghasilkan efek afrodisiak. Kelenjar pituitari juga melepaskan agen kimia ke dalam sirkulasi darah untuk mengatur fungsi kelenjar lain seperti tiroid dan adrenal (Dehkordi, Baharanchi, \& Bekhradi, 2014).

Penelitian yang mendukung efektivitas aromaterapi lavender terhadap dismenorea ialah penelitian yang dilakukan oleh Bakhtshirin et al. (2015) yang berjudul "The Effect of Aromatherapy Massage with Lavender Oil on Severity of Primary Dysmenorrhea in Arsanjan Student" yang dilakukan terhadap 80 remaja putri di Universitas Arsanjan Iran yang mengalami dismenorea dengan memberikan aromaterapi lavender. Hasil akhir menunjukkan aromaterapi lavender efektif dalam mengatasi dismenorea dengan $p$ value 0,001 ( $p$ value $<0,05$ )

Penggunaan aromaterapi lavender dapat menurunkan nyeri dismenorea, yakni aroma yang berasal dari aromaterapi lavender bekerja melalui sistem limbik dan pusat emosi otak. Ketika aromaterapi dihirup, molekul yang mudah menguap dari minyak tersebut dibawa oleh arus udara ke hidung yang terdapat siliasilia yang lembut muncul dari sel-sel reseptor. Ketika molekul-molekul itu menempel pada rambut-rambut tersebut, suatu pesan elektrokimia akan ditransmisikan melalui saluran olfaktori ke dalam sistem limbik. Hal ini akan merangsang memori dan respons emosional. Hipotalamus memunculkan pesan-pesan yang harus disampaikan kebagian lain otak serta bagian badan yang lain. Pesan yang diterima itu kemudian diubah menjadi tindakan yang berupa pelepasan senyawa neurokimia seperti serotonin dan enkefalin yang menyebabkan rileks dan sedatif (Koensoemardiyah, 2009).

Terapi akupresur lebih efektif mengurangi nyeri karena memiliki efek analgesik (Hartono, 2012). Terapi akupresur dan aromaterapi lavender merupakan cara untuk menurunkan nyeri dismenorea dengan cara kerja yang berbeda. Aromaterapi merangsang relaksasi dengan bau yang dihirup oleh seseorang, sedangkan terapi akupresur dengan pemijatan atau penekanan pada titik LI 4 dan ST 36 akan meningkatkan kadar endorfin sehingga lebih cepat menurunkan rasa nyeri. Aroma yang dihirup melalui proses pernapasan, kemudian merangsang kinerja otak dan juga dipengaruhi oleh dalamnya pernapasan (Sharma, 2009) sehingga responden banyak yang mengalami penurunan nyeri dismenorea karena terapi akupresur. Kelemahan dari penelitian ini ialah belum mengendalikan faktor-faktor yang mempengaruhi nyeri, terutama faktor psikososial.

\section{SIMPULAN}

Terdapat perbedaan penurunan intensitas nyeri dismenorea yang signifikan antara tindakan aromaterapi lavender dan terapi akupresur dalam mengatasi dismenorea. Terapi akupresur lebih efektif menurunkan dismenorea daripada aromaterapi lavender.

\section{DAFTAR PUSTAKA}

Bakhtshirin, F., Abedi, S., YusefiZoj, P., Razmjooee, D. (2015). The effect of aromatherapy massage with lavender oil on severity of primary dysmenorrhea in Arsanjan students. Iran J. Nurs Midwifery Res., 20(1): 156-160. 
Benson, R.C. \& Pernoll, M.L. (2009). Obstetrics and gynecology, $9^{\text {th }}$ edition. (Alih bahasa: Primarianti, S.S., Resmisari). Jakarta: Penerbit Buku Kedokteran EGC. (Buku asli diterbitkan 1993).

Bobak, Lowdermilk, Jensen. (2005). Maternity nursing. (Alih bahasa: Maria A. Wijayarini dan Peter I. Anugerah). Jakarta: Penerbit Buku Kedokteran EGC. (Buku asli diterbitkan 1995).

Dehkordi, Z.R., Baharanchi, F.S.H., \& Bekhradi, R. (2014). Effect of lavender inhalation on the symptoms of primary dysmenorrhea and the amount of menstrual bleeding: A randomized clinical trial. Complement Ther. Med., 22(2):212-219.

Ferraz, M.B., Quaresma, M.R., Aquino, L.R., Atra, E., Tugwell, P., \& Goldsmith, C.H. (1990). Reliability of pain scales in the assessment of literate and illiterate patients with rheumatoid arthritis. J. Rheumatol., 17(8):1022-1024.

Gharloghi, S., Torkzahrani, S., Akbarzadeh, A.R., Heshmat, R. (2012). The effects of acupressure on severity of primary dysmenorrhea. Patient Prefer Adherence, 6: 137-142.

Handrawan, H. (2008). IImu kandungan. Jakarta: Yayasan Bina Pustaka.

Hartono, R.I.W. 2012. Akupresur untuk berbagai penyakit dilengkapi dengan terapi gizi medik dan herbal. Yogyakarta: Rapha Publishing.

Hasanah, O. (2010). Efektifitas terapi akupresur terhadap dismenore pada remaja di SMPN 5 dan 13 Pekanbaru (Tesis). Fakultas IImu Keperawatan Universitas Indonesia, Jakarta, Indonesia.

Hegner, B. R. \& Caldwell, E. (2003). Nursing assistant: A nursing process approach, $6^{\text {th }}$ edition. (Alih bahasa: Jane F. Budhi, Allenidekania). Jakarta: Penerbit buku kedokteran EGC. (Buku asli diterbitkan 1992).

Julianti, Hasanah, O., \& Erwin. (2014). Efektifitas akupresur terhadap dismenore pada remaja putri. Jurnal Online Mahasiswa PSIK, 1(2). Retrieved from http://jom.unri.ac.id/index.php/ JOMPSIK/article/view/3449/3345.

Koensoemardiyah. (2009). A-Z Aromaterapi untuk kesehatan, kebugaran, dan kecantikan. Yogyakarta: Andi.

Kozier, B., Glenora, E., Audrey, B., Shirlee, S. (2012). Fundamentals of nursing: Concepts, process, and practice (Second Edition). California: AddisonWesley Publishing Company Inc.

Morgan, G. \& Hamilton, C. (2009). Practice guidelines for osbtetrics \& gynecology (Second edition). (Alih bahasa: Rusi M. \& Ramona). Jakarta: Penerbit Buku Kedokteran EGC. (Buku asli diterbitkan 2002).

Sharma, S. (2009). Aroma terapi (aroma therapy). Tangerang: Kharisma Publishing Group.

Tamsuri, A. (2007). Konsep dan penatalaksanaan nyeri. Jakarta: Penerbit Buku Kedokteran EGC.

Widyaningrum. (2013). Pijat refleksi \& 6 terapi alternatif lainnya. Jakarta: Media Pressindo.

Williamson, A. \& Hoggart, B. (2005). Pain: A Review of Three Commonly Used Pain Rating Scales. J. Clin. Nus., 4(7):798804. 